\title{
Food Bio-Preservation: An Overview with Particular Attention to Lactobacillus plantarum
}

\author{
Noha, Khalil, Nassra, Dabour, El-Ziney, M. \& Kheadr, E. \\ Dairy Science and Technology Dept., Fac. of Agric. University of Alexandria, El-Shatby 21545, \\ Alexandria, Egypt.
}

Received: 12 March, 2021

Revised: 20 May, 2021

Accepted: 27 May, 2021

\begin{abstract}
Food bio-preservation has gained considerable attention during the last decade. It is considered a promising alternative to classical means of food preservations and meets current consumer demands for the consumption of safe, nutritious, and chemicalfree products. The main techniques of food bio-preservation, include the application of bacteriocins, bacteriophages, endolysins, and protective cultures, which compose mainly of lactic acid bacteria. To date, the use of lactic acid bacteria (as protective cultures) or their metabolites in foods is known as the main acceptable tool of food bio-preservation. This review focus on the concept of food bio-preservation and its techniques, and the role of lactic acid bacteria and their antimicrobials in food bio-preservation. Among lactic acid bacteria, particular attention is given to Lactobacillus plantarum, a versatile species with important antimicrobial activity. This species is known to produce numerous bacteriocins and antifungal-active compounds. Also, Lactobacillus plantarum is extensively used in the production of many fermented foods either as a starter culture and probiotic microorganism.
\end{abstract}

Keywords: Bio-preservation, bacterioncin, LAB, L. plantarum, Protective culture.

\section{Food bio-preservation}

Currently, food preservation and safety are the main preoccupation of consumer, and food producer. Food preservation is largely related to the quality and safety of the food product. It is a very crucial issue to prevent foodborne illnesses, which is serious and costly. Food preservation aims to maintain the safety and overall quality of the product (organoleptic and nutritional), reduce the wastage of excess food, extend shelf-life of the product, and preserve the food materials during transportation (Devi et al., 2015).

There are several methods for food preservation, including physical techniques such as conservation at low temperature (refrigeration, and, freezing), and application of thermal treatments (pasteurization, boiling, and sterilization,......). Foods are also preserved by adding some chemical preservatives (sodium chloride, sodium nitrite, benzoates, sorbates...).

These traditional preservation techniques may represent health hazards, alter the sensory of food and lead to the loss of some-nutritive elements. So, the bio-preservation techniques look to be more convenient to improve food quality and safety. Moreover, bio-preservation could extend food shelf life with good hygienic status and minimal adverse effects on nutritional and organoleptic aspects. To date, there is increasing interest to replace traditional food preservation means by combinations of innovative technologies that include biological antimicrobial systems such as LABs or their metabolites (Nath et al., 2014). Indeed, finding natural antimicrobial agents with significant antimicrobial activity has received considerable attention to enhance the quality and shelf-life of a food product. The application of LABs and/or their metabolites to extend the shelf life of foods is known as food bio-preservation (Lin \& Pan, 2017). Besides the application of LAB and their metabolites, food bio-preservation techniques are also relying on the application of bacteriophages and bacteriophageencoded enzymes (e.g., endolysins). These applications are extremely necessary to reduce or prevent the use of chemical preservatives or severe thermal treatments, both of which can adversely affect the safety or quality of food products.

\section{Bio-preservation techniques \\ Bacteriophages}

Bacteriophages, true parasites, are viruses that can multiply only inside the bacterial cells. They are not able to infect or cause damage to human and animal cells (Singh, 2018). Bacteriophages are predominating microorganisms and wide-spread on foods (Brüssow \& Kutter, 2005). The majority of the bacteriophages are composed of a head 
and a double-stranded 179 DNA tail. Based on tail structures, bacteriophages can be classified mainly into three groups as 1) contractile tail, 2) long noncontractile tail and 3) extremely short tail (Ackermann, 2007). Bacteriophages are classified as virulent or temperate viruses. Virulent bacteriophages have lytic life cycle while temperate viruses have a lysogenic cycle by integrating their DNA into the bacterial chromosome (prophage). Virulent bacteriophages are capable to lyse the host bacterium and exerted antimicrobial activity (Hanlon, 2007).

In the field of food preservation, bacteriophages could be used effectively to prevent contamination or colonization of pathogens on food surfaces (e.g., decontamination of carcasses, fresh, fruits, and vegetables). Bacteriophages could be successfully used to control Salmonella sp., Campylobacter sp. and Escherichia coli in poultry and ruminants (Atterbury et al., 2005; Raya et al., 2006). In dairy products, bacteriophages appeared to be efficient to suppress Salmonella, Staphylococcus aureus, and Listeria monocytogenes in different cheese varieties (Kim et al., 2007). Some bacteriophages-based products are approved by the US food and drug administration (FDA) and launched for commercial applications (Singh, 2018). For example, products named Listex ${ }^{\circledR}$ and LMP $102^{\circledR}$ are applied for ready-to-eat meat, as well as products containing anti-E. coli and anti-Salmonella phage to treat live animals before slaughtering (Moye et al., 2018). Further research is still needed to overcome many limitations of phage applications in the food industry including the rise of resistance and intolerance to environmental conditions.

\section{Endolysins}

Endolysins, phage lysins, are phage-encoded peptidoglycan hydrolases employed by the majority of bacteriophages to enzymatically degrade the peptidoglycan layer of the host bacterium. Bacteriophages use the endolysins at the end of their replication cycle to degrade the peptidoglycan of the bacterial host (Oliveira et al., 2013). Endolysins have a high antimicrobial activity particularly against Gram-positive bacteria (Young et al., 2005). Indeed, endolysins have a narrow spectrum of lytic activity and are often restricted to phage host bacterial activity from which they are originally derived (Yoong et al., 2004). To date, development of resistance against endolysins has never been reported. Endolysins have several potential applications, including treatment of mastitis and prevention of $S$. aureus and Listeria sp. biofilms (Turner et al., 2007). Endolysin treatment represents a novel and promising strategy for controlling antibiotic-resistant bacteria, which are a frequently encountered problem in the sector of the food industry (Chang, 2020).

\section{Protective cultures}

The food fermentation process is a typical example of the biological preservation of foods. It leads to the formation of a large number of bacterial cells and the accumulation of beneficial metabolites, which can potentially reduce the incidence of food spoilage and pathogenic microorganisms (Ganguly, 2013). Biological preservatives eligible for application in food must be recognized as a safe, non-pathogenic, non-toxic producer and culturable in food. The biological agents usually used in food bio-preservation are a starter and/or protective cultures. The application of starter cultures is mainly to initiate fermentation, produce organic acids and generate flavour and aroma compounds responsible for typical organoleptic characteristics of the fermented product. However, the protective cultures, due to their antimicrobial activity, are generally used to control growth and reduce the survival of many pathogenic and spoilage-causative microorganisms in foods. In practice, a combination of both cultures is generally recommended for application in the food industry.

\section{Lactic acid bacteria (LABs)}

Lactic acid bacteria (LABs) are recognized as GRAS (generally recognized as safe) and have been used in food fermentation for centuries. LABs are intensively used in the production of a wide variety of fermented dairy, meat, and vegetable products. Lactic acid bacteria are a group of Gram-positive bacteria, nonmotile, non-spore-forming, rod- or cocci-shaped microorganisms and generally characterized by fermenting carbohydrates to mainly produce lactic acid. It is a heterogeneous microbial group that contains 10 bacterial species, including Lactococcus, Streptococcus, Pediococcus, Lactobacillus, Leuconostoc, Enterococcus, Carnobacterium, Oenococcus, Aerococcus, Tetragenococcus, Vagococcus, and Weisella. These microorganisms contain low $\mathrm{G}+\mathrm{C}$ ratio $(<55 \%)$ in their DNA which provides more thermostability to the cells. LABs can possess very interesting characteristics, such as the ability to resist freezing and freeze-drying, ferment citrate, produce exo-polysaccharides and antimicrobial substances, in addition to their resist- 
ance to stressful conditions and ability to colonize the digestive tract. (Singh, 2018).

Fermentation by LABs has been shown to control and suppress a wide variety of both food spoilage and pathogenic microorganisms (Sharma et al., 2012). Food fermentation is the oldest approach of food bio-preservation that has been proven to be efficient to improve food safety and quality. LABs have the ability to extend the shelf life of fermented foods has been attributed to their capacity to produce various inhibitory compounds, including organic acids (lactate, acetate, propionate, etc....), diacetyl, hydrogen peroxide, and many antifungal active molecules, including free fatty acids and phenyl lactic acid (Steele et al., 2013). Also, they can produce inhibitory peptides known as bacteriocins to inhibit pathogenic bacteria and bacteria responsible for food spoilage. The inhibitory effects of these substances have not yet been characterized and are believed to be achieved through a range of different mechanisms (Liu et al., 2011).

\section{Antimicrobials produced by LABs}

The ability of LABs to inhibit other microorganisms is taken as the basis of bio-preservation to enhance the safety and quality of food products. LABs culture with potential inhibitory activity is known as protective culture. The antimicrobials produced by LABs are generally recognized as safe and food-grade molecules and widely accepted for food preservation (Messaoudi et al., 2013).

\section{Organic acids}

Food fermentation by LABs results in significant production of organic acids, as a by-product of their metabolism, which exerts antimicrobial activity (Ross et al., 2002). Lactate, acetate, and propionate are the most common organic acids produced by LABs. Organic acids are implicated centuries in food preservation and they have proven the efficiency to extend the shelf-life many food products. In addition, they are considered normal constituents of fermented products, where they contribute to the sensory characteristics of these products. Organic acids play important role in the preservation of many types of food, such as fermented dairy vegetables and meat products. Production of organic acid is the principal way by which LABs can compete and inhibit other competitors. The organic acids can acidify the surrounding environment to inhibit the growth of many pathogens (Akbar \& Anal, 2014).
Among organic acids, lactate acid is the abundant product acid produced by LABs during the homo-fermentation of hexoses. It is also produced by hetero-fermentation along with acetate, ethanol, and carbon dioxide $\left(\mathrm{CO}_{2}\right)$ (Ross et al., 2002). Lactate is found in many foods either as a product of in situ microbial fermentation (cheeses and yoghurt) or as a food additive; acidulate, in a wide variety of processed foods (soups, mayonnaise, and processed eggs (Datta \& Henry, 2006).

The inhibitory effect of lactate is attributed to the diffusion of its non-dissociated form leading to acidification of cytoplasm and failure of proton motive forces. This affects the $\mathrm{pH}$ gradient of the cell membrane and decreases the available energy for cells to grow (Wee et al., 2006). When present in a mixture with other organic acids, lactate contributes to reduce the acidity, while acetate acid and propionate act as antimicrobial agents by interfering cell membrane maintenance potential of the target cells (Ross et al., 2002).

The inhibitory effect of lactic acid compared with other short-chain organic acids, including for$\mathrm{mic}$, acetic, and propionic acids was investigated at an equal molarity basis. The inhibition was affected by $\mathrm{pH}$ and atmosphere conditions. At $\mathrm{pH}$ of 5.8 versus Yersinia enterocolitica, the inhibitory effect order was formate $>$ acetate $>$ propionate $>$ lactate, whereas, at lower $\mathrm{pH}$ of 3.90 , the inhibitory effect became formate $>$ lactate $>$ acetate $>$ propionate, respectively. This may indicate that the antibacterial activity of short-chain organic acids is molecular size-dependent. However, lactate is enhanced under anaerobic conditions compared to aerobic ones meanwhile, the $Y$. enterocolitica was more tolerant to formate and acetate when cultivated anaerobically (El-Ziney et al., 1997).

Lactate has a significant antifungal activity, which can be improved when mixed with acetate. Pelaez et al. (2012) reported that the mixtures of lactate and acetate had a synergistic effect to inhabit toxigenic strains of Aspergillus flavus.

Acetate is used in many food products as an aroma compound and as an antimicrobial that has abroad spectrum of inhibitory activity against many bacterial species (either Gram-positive or negative), yeasts, and molds. Acetate has stronger antimicrobial activity compared to lactate (Malti $\&$ Amarouch, 2008). Depending on its concentration, acetate can exert bacteriostatic or bactericidal effects. The bacteriostatic activity appears at low 
concentrations $(\leq 0.15 \%)$, but at concentrations above $0.3 \%$ the bactericidal effect is present (Reis et al., 2012). The antimicrobial effect of acetate is attributed to the un-dissociated molecule (Reis et al., 2012).

Basically, propionic acid-producing bacteria (Propionibacterium sp.) have the ability to convert lactate generate large amounts of propionate in addition to acetate and $\mathrm{CO}_{2}$ (Suomalainen et al., 1999). However, hetero-fermentative LABs are able to produce little amounts of propionic acid. Due to its antifungal activity, propionic acid could be used as food preservative. In addition, it has strong activity to to reduce the viability of many bacterial species, including both Gram-positive and Gram-negative bacteria (Reis et al., 2012). Propionate could be used to control molds and yeasts in cheeses, butter, bakery products, and some fresh fruit (Ray, 2004). Its inhibitory effect depends on the decrease in $\mathrm{pH}$ caused by lactic acid. To exert its inhibitory effect propionate interacts with cell membranes to neutralize the electrochemical proton gradient leading to reduction of amino acid uptake and consequently the fungal growth.

\section{Bacteriocins}

Bacteriocins are ribosomally-synthesized peptides that have an antibacterial activity against closely related bacteria (Jack et al., 1995). They are produced both by Gram-positive (Streptococcus, Lactococcus, etc..) and Gram-negative bacteria (Pseudomonas, Escherichia coli, Klebsiella etc..).
The majority of bacteriocins produced by LABs are selectively active against closely related species while Nisin ${ }^{\circledR}$, exceptionally, has antimicrobial activity against many Gram-positive bacteria, including Bacillus sp., and Clostridium botulinum (Hurst, 1981). Bacteriocins produced by LABs are classified into 4 classes (Klaenhammer, 1993) as shown in Table (1). This classification includes:

Class I (lantibiotic bacteriocins): this class includes small peptides $(>4 \mathrm{kDa})$ that contain unusual amino acid residues (lanthionine and $\beta$-methyl lanthionine) as well as dehydrated amino acids, (Xie \& van der Donk, 2004).

Class II (non-lantibiotic bacteriocins): this class includes heat-stable small bacteriocins (4-6 $\mathrm{kDa}$ ). Bacteriocins belonging to this class do not contain unusual amino acids in their composition (Liu et al., 2011). This class could also be divided into tree subclasses, including pediocin-like bacteriocins (IIa), two-peptide bacteriocins (IIb), and circular bacteriocins (IIc) (Cotter et al., 2005), and

Class III: this group includes non-bacteriocin lytic proteins (bacteriolysins), which have large molecular mass (>10 kDa), and heat-labile peptides (Wiedemann et al., 2001).

Class-IV circular peptides: this class contains antimicrobial bacteriocins produced by LABs, plants, and mammalian cells (Burgos et al., 2014; Golneshin et al., 2020).

Among bacteriocins, purified nisin, to our

Table 1: Classification of bacteriocins

\begin{tabular}{|c|c|c|c|}
\hline Classes & Characterization & Bacterioicn/producer organism & Reference \\
\hline $\begin{array}{l}\text { I- } \\
\text { Lantibiotics }\end{array}$ & $\begin{array}{l}\text { - They contain thioether-intramolecu- } \\
\text { lar rings of lanthionine and } \beta \text {-methyl- } \\
\text { lanthionine }\end{array}$ & $\begin{array}{l}\text { - Nisin/lactococcus lactis subsp. di- } \\
\text { acetylactis }\end{array}$ & $\begin{array}{l}\text { Xie and van der } \\
\text { Donk (2004) }\end{array}$ \\
\hline $\begin{array}{l}\text { II- } \\
\text { Non-lantibiotics }\end{array}$ & $\begin{array}{l}\text { - They are linear short cationic pep- } \\
\text { tides }(<10 \mathrm{kDa}) \text { with high isoelectric } \\
\text { points. } \\
\text { - They are divided into three subclass- } \\
\text { es }(\mathrm{a}, \mathrm{b} \text {, and } \mathrm{c}) \text {. }\end{array}$ & $\begin{array}{l}\text { - Pediocin PA-1 \& AcH/ pediococci. } \\
\text { - Enterocin EJ97/ Enterococcus faeca- } \\
\text { lis } \\
\text { - Enterocin L50A/ Enterococcus fae- } \\
\text { calis }\end{array}$ & $\begin{array}{l}\text { Papagianni \& } \\
\text { Anastasiad- } \\
\text { ou(2009) }\end{array}$ \\
\hline $\begin{array}{l}\text { III-large bacte- } \\
\text { riocins }\end{array}$ & $\begin{array}{l}\text { - They are large ( }>30 \mathrm{KDa}) \text { heat-la- } \\
\text { bile proteins. } \\
\text { - They contain a peptide bond between } \\
\text { the } \mathrm{C} \text { - and N-terminus. }\end{array}$ & $\begin{array}{l}\text { - Helveticin J/ Lactobacillus helveti- } \\
\text { cus } \\
\text { - Bacteriocin Bc-48 /Enterococcus } \\
\text { faecalis }\end{array}$ & $\begin{array}{l}\text { Wiedemann et } \\
\text { al. }(2001)\end{array}$ \\
\hline $\begin{array}{l}\text { IV - cyclic } \\
\text { bacteriocins }\end{array}$ & $\begin{array}{l}\text { - They are circular peptides produced } \\
\text { by bacteria, plants, and mammalian } \\
\text { cells. } \\
\text { - They contain a peptide bond between } \\
\text { the C- and N-terminus. }\end{array}$ & $\begin{array}{l}\text { - Enterocin AS-48 /Enterococcus fae- } \\
\text { calis } \\
\text { - Plantacyclin B21AG / Lactobacillus } \\
\text { plantarum B21 }\end{array}$ & $\begin{array}{l}\text { Burgos et al. } \\
\quad(2014) \\
\text { Golneshin et al. } \\
\quad(2020)\end{array}$ \\
\hline
\end{tabular}


knowledge, is the only bacteriocin licensed for addition to foods (Schillinger et al., 1996). Another interesting antimicrobial peptide that belongs to Class IIa bacteriocin is pediocin PA-1. Pediocin PA-1 is not approved as pure substance by FDA however, one commercial crude fermentation product distributed as Alta 2341 (Quest International) (Lopez-Cuellar et al., 2016) or CHOOZIT ${ }^{\mathrm{TM}}$ FLAV 43 (Danisco) which is lyophilized pediocin producing cultures (Papagianni \& Anastasiadou, 2009). MicroGARD ${ }^{\circledR}$ fermentates are skim milk fermented by LABs contains potent inhibitors toward Gramnegative and Gram-positive bacteria and yeast and fungi (DUPONT) and approved by FDA (Makhal et al., 2015).

Bacteriocins produced by LABs have several advantages that make them promising for food preservation. This because LABs are implicated in food fermentation for centuries and have a proven history of safety, thereby their metabolites are generally recognized as safe. Also, none of the LABs bacteriocins have shown a toxic effect against eukaryotic cells. Also, the proteinaceous nature of bacteriocins ensures their safety as they become inactive by digestive proteases (Drider et al., 2006).

Bacteriocins can exert a bactericidal effect at the membrane level, which is effective to inhibit antibiotic-resistant microorganisms (Thomas et al., 2000). The thermal and $\mathrm{pH}$ stability of bacteriocins make them a promising candidate to be used as a food preservative. The genetic determinants responsible for bacteriocin production are usually located on plasmids, which could be transferred from donor to recipient cells leading to improve the characteristics of bacteriocin-producing strain. The application of bacteriocins as a food preservative has many aspects, including (1) reduction of the incidence of food poisoning, cross-contamination, and the use of chemical preservatives, and (2) improve quality and extend the shelf-life of food products (Gálvez et al., 2007). There are different ways to apply bacteriocins in foods, including the application of producer strains, the addition of free or encapsulated (Gálvez et al., 2007).

The mechanism of bacteriocins action is principally attributed to the formation of a pore in the bacterial cell membrane (Sahl \& Bierbaum, 1998), leading to the efflux of small molecules such as amino acids, potassium ions, and ATP (Lins et al., 1999). Other mechanisms have been proposed to describe the mechanism of bacteriocins action on the bacterial cells. Bacteriocins could induce the activity of cell-wall acting enzymes (amidases) through the release of the enzymes from their inhibitors (teichoic and teichuronic acids) leading to bacterial autolysis (Severina et al., 1998). Bacteriocins may also act on specific intracellular targets, including induction of proteolytic enzyme production, metabolic disorder, and reduction of respiratory function (Sahl \& Bierbaum, 1998). This may explain the formation of lysis vesicles previously reported by Benech et al. (2002) in cells of Listeria innocua and Lactobacillus casei subsp. casei treated with nisin $\mathrm{Z}$.

LABs-producing bacetriocins and their metabolites are of particular interest to the food industry. For the bio-preservation of foods, LABs-producing bacteriocins and their metabolites could be applied to foods through three approaches. First is the direct application of LABs-producing bacteriocins, which produce the bacteriocin into foods during food processing. The second approach is the direct addition of the purified or crude bacteriocins onto the food product and lastly is applied to a previously fermented product from a bacteriocin-producing strain (Lin \& Pan, 2017).

\section{Reuterin}

Reuterin (3-HPA) has an effective wide spectrum inhibitory action against Gram-positive and -negative bacteria, yeast, moulds, viruses, and protozoa (El-Ziney et al., 2000). It is known that Gram-negative bacteria are more susceptible to reuterin than Gram-positive. Reuterin is produced by some LABs, particularly Lactobacillus reuteri, during the anaerobic fermentation of the glycerol (Axelsson et al., 1989). It can also be produced by L. coryniformis, L. brevis, L. collinoides, and L. buchneri (Nakanishi et al., 2002). Reuterin was successfully able to inhibit Escherichia coli O157:H7 and Listeria monocytogenes in milk and cheese (El-Ziney \& Debevere, 1998) and extend the shelflife of fermented milk products, without drastically affecting their quality parameters (Ortiz-Rivera et al., 2016).

Reuterin-producing LABs showed antifungal activity against many yeasts and moulds, including members belong to species Candida, Saccharomyces, Torulopsis, Aspergillus, and Fusarium (Chung et al., 1989). The addition of glycerol to the growth medium of these LABs induces their antifungal activity (Magnusson \& Schnurer, 2001). 


\section{Hydrogen peroxide $\left(\mathrm{H}_{2} \mathrm{O}_{2}\right)$}

Some LABs produce $\mathrm{H}_{2} \mathrm{O}_{2}$ during their growth that can improve self-life and inhibit the growth of many pathogenic microorganisms in food (Dahiya \& Speck, 1968). Hydrogen peroxide-producing LABs are able to inhibit the growth of many psychrotrophic microorganisms at refrigeration temperatures. The formation of $\mathrm{H}_{2} \mathrm{O}_{2}$ is taken place through the oxidization of lactatic acid. Lactobacilli implicated in meat fermentation such as $L$. plantarum, L. sakei, and L. pentosus have hemedependent catalase activity, which adversely affects the organoleptic properties by increasing the rancidity, due to fat oxidation, and discoloration of the final products (Ammor \& Mayo, 2007).

Hydrogen peroxide exerts strong bactericidal and fungicidal effects (Brul \& Coote, 1999). Biologically, $\mathrm{H}_{2} \mathrm{O}_{2}$ is a component of the lactoperoxidase system, found in milk, in addition to thiocyanate. This system has strong antimicrobial activity against bacteria and fungi. It is primarily active against microorganisms that produce $\mathrm{H}_{2} \mathrm{O}_{2}$ (Seifua et al., 2005). Many LABs especially those that belong to lactobacilli produce sufficient $\mathrm{H}_{2} \mathrm{O}_{2}$ to activate the lactoperoxidase system (Wolfson \& Sumner, 1993). As $\mathrm{H}_{2} \mathrm{O}_{2}$ is not normally detected in raw milk (FAO, 1999), it is permitted to add $\mathrm{H}_{2} \mathrm{O}_{2}$ at a concentration of 100-800 ppm (Luck, 1962) for the preservation of raw milk in the absence of refrigeration. Thus, $\mathrm{H}_{2} \mathrm{O}_{2}$ may be added or generated by the addition of sodium percarbonate or glucose oxidase to activate the lactoperoxidase system (Kussendrager \& van Hooijdonk, 2000).

\section{Carbon dioxide $\left(\mathrm{CO}_{2}\right)$}

During the hetero-fermentation of hexoses, LABs can produce carbon dioxide as lactic acid. Hetero-fermenters LABs can produce large quantities of $\mathrm{CO}_{2}$. The antimicrobial activity of $\mathrm{CO}_{2}$ is attributed to its ability to create anaerobic conditions and replace the oxygen in the food products. This ability could be used to prevent the growth of spoilage microorganisms, including bacteria and fungi, in foods (Lindgren \& Dobrogosz, 1990). The antibacterial activity of $\mathrm{CO} 2$ is attributed to its capacity to create anaerobic environment and its ability to act as a potential antimicrobial agent. Indeed, a lower concentration of carbon dioxide can stimulate the growth of some microorganisms, but a higher concentration prevents the growth of many of them (Borneman et al., 2012). Gram-neg- ative bacteria are more sensitive to carbon dioxide as compared to Gram-positive bacteria (Akbar \& Anal, 2011). Carbon hydroxide are extensively used in food preservation through modified atmosphere packaging.

\section{Diacetyl}

Diacetyl production is produced by many genera of LABs, including lactococci, lactobacilli, and Leuconostoc (Clark et al., 2015). It is produced mainly through citrate metabolism (Malti \& Amarouch, 2008). Diacetyl is active mainly against Gram-negative bacteria through its reaction with some amino acids, particularly arginine, during utilization of amino acids (Malti \& Amarouch, 2008). It is considered one of the main aroma components in dairy products. Diacetyl concentration varies widely among dairy products. Its concentration in butter ranges from 0.4 to $4.0 \mathrm{ppm}$ (Chrysan, 2005) and yoghurt may contain higher levels up to 16 ppm (Güler \& Gürsoy-Balci, 2011). The American Food and Drug Administration (FDA) considers diacetyl to have GRAS status (Birkenhauer \& Oliver 2003). Diacetyl is lethal against Gram-negative bacteria, inhibitory for Gram-positive bacteria but ineffective against clostridia even under anaerobic conditions (Jay, 1982).

\section{Antifungal compounds}

Spoilage of food by molds and yeasts (known collectively as fungi) is responsible for considerable economic losses and food waste. These microorganisms have important proteolytic and lipolytic activities, and could potentially deteriorate the sensorial quality of many food products (Pitt \& Hocking, 2009). The annual fungal attacks on wheat, maize, and rice have been estimated to cause an economical loss of $\$ 60$ billion in crops worldwide (Varsha \& Nampoothiri, 2016). Microbial spoilage of foods with molds may pose health threats to humans and animals due to poisonous compounds (mycotoxins) produced by many fungal species (Milicevic et al., 2016). Many chemical preservatives (e.g. potassium sorbate, sulfur dioxide, and calcium propionate) are usually added to food to control yeasts and molds. The majority of these chemical preservatives have limited efficiency and may adversely affect the overall product quality (Bata \& Lasztity, 1999). Thus, the use of LABs and their antifungal metabolites offers the best alternative to chemical preservatives. In general, LABs are considered "Green preservatives" due to 
their safety and ability to inhibit fungal growth in food without causing adverse effects on the sensorial quality and nutritional value of food products (Pawlowska et al., 2012).

Kim (2005) reported that five strains of LABs, isolated from Kimchi product, had a wide antifungal activity against strong activity against Aspergillus fumigatus, Aspergillus flavus, Penicillium commune and Fusarium moniliforme). The isolates were further identified as Lactobacillus sakei, Lactococcus lactis subsp. lactis, Lactobacillus pentosus, Lactobacillus casei, and Lactobacillus cruvatus. Probiotic strains with potential antifungal activity were used in bread fermentation with yeast to challenge the growth and aflatoxin production by Aspergillus parasiticus and Penicillium expansum (Saladino et al., 2016). The probiotic strains could reduce the production of aflatoxin(s) by 84.1 to $99.9 \%$ and extend the shelf-life of bread by about 3-4 days. In an attempt to develop antifungal cultures to be used for the bio-preservation of dairy products Salas et al. (2018) screened 32 strains of LABs and propionibacteria for their antifungal activity against Penicillium commune, Mucor racemosus, Galactomyces geotrichum, and Yarrowia lipolytica. Two antifungal cultures containing $L$. plantarum L244 along with L. harbinensis L172 or L. rhamnosus CIRM-BIA1113 could effectively delay the growth of $M$. racemosus, $P$. commune, and Rhodotorula mucilaginosa without effect on organoleptic properties of sour cream. Both Pediococcus pentosaceus KTU05-10, and Pediococcus acidilactici KTU05-7 have strong antifungal activity. They were able to suppress growth of Fusarium poae, and Fusarium culmorum (Juodeikienea et al., 2018). Also, these microorganisms could reduce the formation of deoxynivalenol, zearalenone, T-2 and HT-2 toxins by $23,34,58$, and $73 \%$ respectively. In addition, treatment of wheat grains with permeate previously fermented with $P$. acidilactici KTU05-7 and $P$. pentosaceus KTU05-10 strains resulted in increased germination of wheat grains by 9.5 and $7.9 \%$, respectively.

Earlier studies on antifungal activity of LABs indicated the ability of Lactobacillus plantarum to inhibit fungi is attributed to its ability to produce phenylacetic acid and 4-hydro phenyl lactic (Lavermicocca et al., 2000). Also, bacteriocin-like substances and compounds with low molecular weight that can be produced by $L$. plantarum, $L$. pentosus and $L$. coryniformis have been shown to exert antifungal activity (Magnusson et al., 2003). In general, the antifungal metabolites produced by LABs include organic acids as phenylacetic, hydroxyphenyllactic, benzoic acids, fatty acids, volatile compounds (such as diacetyl, acetoin), cyclic dipeptides, hydrogen peroxide, reuterin, and/or proteinaceous compounds (Salas et al., 2017).

\section{Lactobacillus plantarum protective action}

\section{Importance of $\boldsymbol{L}$. plantarum}

The species Lactobacillus plantarum is one of the most important members of the genus Lactobacillus. This species is extensively implicated in the food industry either as a starter culture or probiotic microorganism. L. plantarum is a versatile species with important and diverse characteristics. The species can be found in many raw and fermented food products (Guidone et al., 2014). L. plantarum has been shown to have a crucial role in the flavor development and texture of a wide variety of fermented foods, including dairy products, fermented meat and fermented vegetables (Adesulu-Dahunsi et al., 2017). Also, L. plantarum is known to be a good source of many enzymes, including ester hydrolases (Kim et al., 2017), lipase (Uppada et al., 2017), lactate dehydrogenase (Krishnan et al., 2000), and $\alpha$-Amylase (Panda \& Ray, 2008). $L$. plantarum has been shown to produce a wide range of proteolytic enzymes with potential application in dairy sector (Tchorbanov et al., 2011).

In addition, $L$. plantarum has the ability to enhance the nutritional quality and vitamin contents of many food products (Swain \& Ray, 2016; Panda et al., 2017). It could increase the vitamin concentrations like folate, riboflavin, vitamin B12 in yogurt (Li et al., 2017). It can also produce large amounts of vitamin B12 in fermented foods (Arena et al., 2014).

L. plantarum has been shown to have significant effects on the flavor and texture development in many fermented foods (Adesulu-Dahunsi et al., 2017). Several strains of L. plantarum have been shown to improve the overall quality of many fermented foods, including taste and aroma enhancement, nutritional attributes and health-promoting activities (Lee et al., 2016).

L. plantarum is characterized by its ability to produce antimicrobial cyclic dipeptides. L. plantarum strain LBP-K10 has been shown to produce antimicrobial cyclic dipeptides active against mul- 
tidrug-resistant bacteria, pathogenic fungi, and influenza A virus Kwak et al. (2017).

Some strains of $L$. plantarum have been shown to produce exopolysaccharides (EPS) with potential application in the food industry. EPS are biopolymers with a high molecular weight that produced extracellularly by some microorganisms (bacteria, fungi, and algae) and considered food-grade biopolymers (Zhou et al., 2016). Numerous strains of EPS-producing L. plantarum have been isolated from fermented foods (yoghurt, cheese, fermented meat, etc.......). L. plantarum KF5, isolated from Tibet kefir, could produce EPS consisted of glucose and mannose (Wang et al., 2010). L. plantarum strain C88 (isolated from tofu) has been shown to produce exo-polysaccharide composed of glucose and galactose at molar ration of 2:1, respectively and a molecular mass of $1.1 \times 10^{6} \mathrm{Da}$ (Zhang et al., 2013). Another strain of L. plantarum 7081, isolated from Chinese fermented product, has been shown to produce EPS composed of glucose, mannose, and galactose with a molecular mass of 203 $\mathrm{kDa}$ (Wang et al., 2015). Gangoiti et al. (2017) isolated an EPS producer strain, known as L. plantarum CIDCA 8327, from kefir. The EPS produced by this strain have promising functional properties to improve physical characteristics of functional foods. The strain L. plantarum K041 described as high EPS producer was isolated from traditional Chinese pickles (An et al., 2017).

In addition to its antimicrobial activity, $L$. plantarum is considered a probiotic promising candidate. This microorganism has potential antioxidant, antimutagenic, and immune-stimulating activities. There is increased attention to apply $L$. plantarum in medical sectors for the treatment of Alzheimer's, Parkinson's, diabetes, cardiovascular diseases, cancer, obesity, hypercholesterolemia, hypertension, urinogenital complications, gastrointestinal disorder, and liver disease (Murofushi et al., 2015).

\section{Antimicrobial activity of $L$. plantarum}

\section{Bacteriocins production}

L. plantarum has been shown to produce a wide variety of bacteriocins known as plantricins (Table 2). Indeed, L. plantarum can produce bacteriocins of high and broad activity targeting many pathogenic microorganisms such as Listeria monocytogenes, Staphylococcus aureus, and Aeromonas hydrophila (Bernbom et al., 2006; Messi et al.,
2001). Plantaricins, common bacteriocins produced by L. plantarum, are two peptides of bacteriocins. L. plantarum MBSa4, isolated from fermented sausage, has been shown to produce bacteriocin known as M1-UVs300 (Barbosa et al., 2016). The bacteriocin-M1- UVs300 was described as heat resistant and active against Gram-positive and Gramnegative bacteria over a range of $\mathrm{pH}(2-8)$ (An et al., 2017). This bacteriocin has also shown antagonistic properties to fungi (Barbosa et al., 2016).

L. plantarum NTU 102, isolated from homemade Korean pickled cabbage, has shown an antimicrobial activity against Vibrio parahaemolyticus (Lin \& Pan, 2017). This antimicrobial activity has been shown to decrease by the proteolytic enzymes (e.g., trypsin, pepsin, and proteinase K). Interestingly, antibacterial activities of bacteriocin produced by strain L. plantarum NTU102 remained constant within a $\mathrm{pH}$ range from 1.0 to 4.0 but disappeared at $\mathrm{pH}>5.0$. The bacteriocin also lost its inhibitory effect after heating at $121^{\circ} \mathrm{C} / 15 \mathrm{~min}$. It has been recommended to use this strain as biopreservative to control Vibrio parahaemolyticus in food. L. plantarum B21, isolated from Vietnamese sausage, displayed antimicrobial activity against Clostridium perfringens, and Listeria monocytogenes (Golneshin et al., 2020). This activity was attributed to its ability to produce a thermostable circular peptide (bacteriocin) known as plantacyclin B21AG. The peptide (5668 Da) demonstrated resistance to a wide range of $\mathrm{pH}$ and proteolytic enzymes.

\section{Antifungal activity}

The antifungal activity exerted by L. plantarum is well documented and many studies have reported on its role in inhibiting the growth of a wide variety of moulds and yeasts (Crowley et al., 2013). Among 897 isolates of LABs, originated from fruits, vegetables, and herbs, 12 strains belonging to L. plantarum were found to have strong antifungal activity (Cheong et al., 2014). The strain L. plantarum YML007, isolated from kimchi, has a strong antifungal effect against Aspergillus flavus, A. oryzae, and Fusarium oxysporum (Rather et al., 2013). The antifungal activity of this strain was attributed to its ability to produce a novel protein of $1.256 \mathrm{kDa}$. Numerous strains of L. plantarum have been shown the ability to produce antifungal bioactive peptides active against Aspergillus parasiticus and $P$. expansum (Luz et al., 2017). Also, Russo et al. (2017) screened 88 strains of L. plantarum for 
Table 2. Common plantricins produce by Lactobacillus plantarum

\begin{tabular}{|c|c|c|c|c|c|}
\hline $\begin{array}{c}\text { Types of } \\
\text { plantricins }\end{array}$ & Strains & $\begin{array}{l}\text { Source of } \\
\text { Isolate }\end{array}$ & $\begin{array}{c}\text { Molecular } \\
\text { mass (kDa) }\end{array}$ & Target organism(s) & Reference \\
\hline Plantaricin $\mathrm{T}$ & L. plantarum LPCO10 & $\begin{array}{l}\text { Fermented } \\
\text { green olive }\end{array}$ & ND & $\begin{array}{l}\text { Clostridium tyrobutyricum } \\
\text { Enterococcus faecalis }\end{array}$ & $\begin{array}{l}\text { Jiménez-Díaz et } \\
\text { al. (1993) }\end{array}$ \\
\hline Plantacin 154 & L. plantarum LTF 154 & $\begin{array}{l}\text { Fermented } \\
\text { sausage }\end{array}$ & $\leq 3.0$ & $\begin{array}{l}\text { Bacillus spp., Staphylococ- } \\
\text { cus aureus, } \\
\text { Salmonella typhimurium }\end{array}$ & $\begin{array}{l}\text { Kanatani \& Os- } \\
\text { himura (1994) }\end{array}$ \\
\hline Plantaricin 149 & L. plantarum NRIC 149 & Pineapple & 2.2 & $\begin{array}{l}\text { Listeria monocytogenes, } \\
\text { Staphylococcus aureus }\end{array}$ & $\begin{array}{l}\text { Kato et al. } \\
\text { (1994) }\end{array}$ \\
\hline Plantaricin F & L. plantarum BF001 & $\begin{array}{l}\text { Spoiled catfish } \\
\text { fillets }\end{array}$ & $0.4-6.7$ & $\begin{array}{l}\text { Staphylococcus aureus, } \\
\text { Salmonella typhimurium, } \\
\text { Listeria monocytogenes, }\end{array}$ & $\begin{array}{l}\text { Fricourt et al. } \\
\quad \text { (1994) }\end{array}$ \\
\hline Plantaricin $\mathrm{C}$ & L. plantarum LL441 & $\begin{array}{l}\text { Cabrales } \\
\text { cheese }\end{array}$ & 3.5 & Listeria monocytogenes & $\begin{array}{l}\text { González et al. } \\
\text { (1994) }\end{array}$ \\
\hline $\begin{array}{l}\text { Plantaricin } \\
\text { LC74 }\end{array}$ & L. plantarum LC74 & $\begin{array}{l}\text { Crude goat's } \\
\text { milk }\end{array}$ & $\leq 5$ & $\begin{array}{l}\text { L. plantarum DSM20174 } \\
\text { Leuconostoc paramesen- } \\
\text { teroides DSM } 20288\end{array}$ & $\begin{array}{l}\text { Rekhif et al. } \\
\text { (1994) }\end{array}$ \\
\hline Plantaricin $\mathrm{C}$ & L. plantarum LL441 & $\begin{array}{l}\text { Cabrales } \\
\text { cheese }\end{array}$ & 3.5 & Listeria monocytogenes & $\begin{array}{l}\text { González et al. } \\
\text { (1994) }\end{array}$ \\
\hline Plantaricin SA6 & L. plantarum SA6 & $\begin{array}{l}\text { Fermented } \\
\text { sausage }\end{array}$ & 3.4 & $\begin{array}{l}\text { L. plantarum, Lactobacillus } \\
\text { brevis, Listeria grayi }\end{array}$ & $\begin{array}{l}\text { Rekhif et al. } \\
\text { (1995) }\end{array}$ \\
\hline Plantaricin $\mathrm{S}$ & L. plantarum LPCO10 & $\begin{array}{l}\text { Fermented } \\
\text { green olive }\end{array}$ & 2.5 & $\begin{array}{l}\text { Clostridia, Propionibacteria, } \\
\text { and Enterococcus faecalis }\end{array}$ & , Jimenez et al. \\
\hline Plantaricin UG1 & 1L. plantarum UG1 & Dry sausage & $3.0-10.0$ & $\begin{array}{l}\text { Listeria monocytogenes } \\
\text { LMG10470 }\end{array}$ & $\begin{array}{c}\text { Enan et al. } \\
(1996)\end{array}$ \\
\hline Plantaricin 423 & L. plantarum 423 & Sorghum beer & 3.5 & $\begin{array}{l}\text { Bacillus cereus, Clostridium } \\
\text { sporogenes, and Enterococ- } \\
\text { cus faecalis, }\end{array}$ & $\begin{array}{c}n \text { Van Reenen et } \\
\text { al. (1998) }\end{array}$ \\
\hline Plantaricin $35 d$ & L. plantarum 35d & \multicolumn{2}{|c|}{ Italian sausages 4.5} & $\begin{array}{l}\text { inhibitory activity against } \\
\text { pathogenic bacteria, }\end{array}$ & $\begin{array}{l}\text { Messi et al. } \\
\quad(2001)\end{array}$ \\
\hline Plantaricin W & \multicolumn{2}{|c|}{ L. plantarum LMG 2379Wine } & 2.3 & $\begin{array}{l}\text { Listeria monocytogenes } \\
\text { Bacillus cereus, and Staphy- } \\
\text { lococcus aureus }\end{array}$ & $\begin{array}{l}\text { Holo et al. } \\
\quad(2001)\end{array}$ \\
\hline Plantaricin C19 & L. plantarum $\mathrm{C} 19$ & $\begin{array}{l}\text { Fermented } \\
\text { cucumbers }\end{array}$ & 3.8 & Listeria monocytogenes & $\begin{array}{l}\text { Atrih et al. } \\
\quad(2001)\end{array}$ \\
\hline Plantaricin JK & L. plantarum $\mathrm{C} \backslash 1$ & $\begin{array}{l}\text { Fermented } \\
\text { cucumbers }\end{array}$ & $3.4-3.7$ & L. plantarum 965 & $\begin{array}{l}\text { Diep et al. } \\
\text { (2003) }\end{array}$ \\
\hline $\begin{array}{l}\text { Plantaricin } \\
\text { ST28MS }\end{array}$ & L. plantarum ST28MS & Molasses & ND & $\begin{array}{l}\text { Lactobacillus casei, } \\
\text { Staphylococcus aureus, and } \\
\text { Enterococcus faecalis }\end{array}$ & $\begin{array}{c}\text { Todorov, \& } \\
\text { Dicks (2005) }\end{array}$ \\
\hline $\begin{array}{l}\text { Plantaricin - } \\
163\end{array}$ & L. plantarum 163 & $\begin{array}{l}\text { Chinese } \\
\text { fermented } \\
\text { vegetables }\end{array}$ & 3.5 & $\begin{array}{l}\text { Staphylococcus aureus, } \\
\text { Listeria monocytogenes, }\end{array}$ & Hu et al. (2013) \\
\hline $\begin{array}{l}\text { Plantaricin } \\
\text { ZJ008 }\end{array}$ & L. plantarum ZJ008 & Fresh milk & 1,3 & $\begin{array}{l}\text { Micrococcus luteus, } \\
\text { Staphylococcus aureus }\end{array}$ & Zhu et al. (2014) \\
\hline Plantaricin ZJ5 & L. plantarum ZJ5 & $\begin{array}{l}\text { fermented } \\
\text { mustard }\end{array}$ & 4.5 & $\begin{array}{l}\text { Staphylococcus aureus, } \\
\text { Listeria monocytogenes }\end{array}$ & $\begin{array}{l}\text { Song et al. } \\
(2014)\end{array}$ \\
\hline Plantaricin Y & L. plantarum 510 & $\begin{array}{l}\text { Japanese white } \\
\text { wine grape }\end{array}$ & 4.2 & Listeria monocytogenes & $\begin{array}{l}\text { Chen et al. } \\
\text { (2014) }\end{array}$ \\
\hline $\begin{array}{l}\text { Plantaricin } \\
\text { ST8SH }\end{array}$ & L. plantarum ST8SH & Salami & ND & $\begin{array}{l}\text { L. monocytogenes ScottA } \\
\text { and E. faecalis ATCC }\end{array}$ & $\begin{array}{l}\text { Todorov et al. } \\
\text { (2016) }\end{array}$ \\
\hline $\begin{array}{l}\text { Plantaricin } \\
\text { JLA-9 }\end{array}$ & $\begin{array}{l}\text { L. plantarum } \\
\text { JLA-9 }\end{array}$ & $\begin{array}{l}\text { Fermented cab- } \\
\text { bage }\end{array}$ & $<1.0$ & $\begin{array}{l}\text { Staphylococcus aureus } \\
\text { Micrococcus luteus }\end{array}$ & $\begin{array}{l}\text { Zhao et al. } \\
\quad(2016)\end{array}$ \\
\hline Plantaricin K25 & L. plantarum K25 & Kimchi & 1.7 & $\begin{array}{l}\text { Bacillus cereus ATCC } \\
14579 \text {, } \\
\text { Listeria monocytogenes } \\
\text { NCTC } 10890\end{array}$ & $\begin{array}{l}\text { Wen et al. } \\
\text { (2016) }\end{array}$ \\
\hline Plantaricin DL3 & L. plantarum DL3 & $\begin{array}{l}\text { Chinese } \\
\text { fermented cab- } \\
\text { bage }\end{array}$ & 3.5 & $\begin{array}{l}\text { Listeria monocytogenes, } \\
\text { Pseudomonas aeruginosa }\end{array}$ & Lv et al., (2018a) \\
\hline $\begin{array}{l}\text { Plantaricin } \\
\text { JY22 }\end{array}$ & L. plantarum JY22 & $\begin{array}{l}\text { Golden carp in- } \\
\text { testine }\end{array}$ & -4.1 & $\begin{array}{l}\text { Bacillus cereus } \mathrm{CMCC} \\
63301\end{array}$ & $\begin{array}{l}\text { Xinran et al. } \\
(2018)\end{array}$ \\
\hline $\begin{array}{l}\text { Plantacyclin } \\
\text { B21AG }\end{array}$ & L. plantarum B21 & $\begin{array}{l}\text { Vietnamese } \\
\text { sausage }\end{array}$ & 5.7 & $\begin{array}{l}\text { Listeria monocytogenes } \\
\text { Clostridium perfringens }\end{array}$ & $\begin{array}{c}s \text { Golneshin et al. } \\
(2020)\end{array}$ \\
\hline
\end{tabular}


their antifungal activity against Aspergillus flavus, Aspergillus niger, Penicillium expansum, Penicillium chrysogenum, Penicillium roqueforti, Fusarium culmorum, and Cladosporium spp. The author reported a significant phenotypic heterogeneity among the antifungal activity trait. Among tested fungal species, A. niger, A. flavus, $P$. roqueforti, and Cladosporium spp. Exhibited strong resistance toward the antifungal metabolites produced by $L$. plantarum. Approximately, 60 to $80 \%$ of L. plantarum strains were unable to affect growth of tested moulds. However, $75 \%$ of the L. plantarum strains showed a strong inhibitory effect against $F$. culmorum, $P$. expansum, and $P$. chrysogenum (Russo et al., 2017). Phenotypic variation corresponded to ten different genotypes that were associated with the ability of $L$. plantarum to produce antifungal metabolites (Dong et al., 2017). Indeed, numerous studies have been reported on the antifungal activity of L. plantarum (Muhialdin et al., 2016; Lv et al., 2018b; Quattrini et al., 2018).

Antifungal activities of $L$. plantarum strains have been attributed to the ability to produce phenyl lactic acid, cyclic dipeptides, fatty acids, and organic acids (Dong et al., 2017). Gupta and Srivastava (2014) studied the antifungal peptides produced by L. plantarum (LR14) against spoilage fungi (Mucor racemosus, Aspergillus niger, Rhizopus stolonifer and Penicillium chrysogenum). The peptides delayed the hyphal growth and spore germination of all tested moulds. Besides, L. plantarum showed a high ability to bind mycotoxins (Dong et al., 2017).

\section{CONCLUSION}

The species $L$. plantarum is a significant member of the genus Lactobacillus. It has potential application in the food industry either as a starter culture or a candidate microorganism with potential probiotic activity. Members of the species have important technological and probiotic properties and can be integrated into many fermented food products. They have wide the ability to produce a wide range of antimicrobials to control food spoilage and pathogenic microorganisms. Also, L. plantarum is considered an excellent candidate for the sector of food bio-preservation. In this concept, studies are needed to characterize the microbial ecosystem of Egyptian foods to elucidate the role of $L$. plantarum in food technology and preservation.

\section{ACKNOWLEDGMENT}

The authors would like to express their deep thank to the science and technology development fund (STDF) and the Egyptian Ministry of Scientific Research for supporting this research through the project: US C18 ID 1073.

\section{REFERENCES}

Ackermann, H.W. 2007. 5500 Phages examined in the electron microscope. Archives of Virology, 152: 227-243.

Adesulu-Dahunsi, A.T., Sanni, A.I., Jeyaram, K. \& Banwo, K. 2017. Genetic diversity of Lactobacillus plantarum strains fromsome indigenous fermented foods in Nigeria. LWT- Food Science and Technology, 82: 199-206.

Akbar, A., \& Anal, A. K. 2014. Zinc oxide nanoparticles loaded active packaging a challenge

study against Salmonella typhimurium and Staphylococcus aureus in ready-to-eat poultry meat. Food Control, 38:88-95.

Akbar, A., \& Anal, A.K. 2011. Food safety concerns and food-borne pathogens, Salmonella, Escherichiacoli and Campylobacter. FUUAST Journal of Biology, 1:5-17.

Ammor, M.S., \& Mayo, B. 2007. Selection criteria for lactic acid bacteria to be used as functional starter cultures in dry sausage production: an update. Meat Science, 76:138-146.

An, Y., Wang, Y., Liang, X., Huaxi, Zuo, Z., Xu, X., Zhang, D., Yu, C., \& Han, X. 2017. Purification and partial characterization of M1UVs300, a novel bacteriocin produced by Lactobacillus plantarum isolated from fermented sausage. Food Control, 81: 211-217.

Arena, M. P., Fiocco, D., Massa, S., Capozzi, V., \& Russo, P. 2014. Lactobacillus plantarum as a strategy for an in situ production of vitamin B2. Journal of Food and Nutritional Disorders, S1-004.

Atrih, A., Rekhif, N., Moir, A.J., Lebrihi, A., \& Lefebvre, G. 2001. Mode of action, purification and amino acid sequence of plantaricin $\mathrm{C} 19$, an anti-Listeria bacteriocin produced by Lactobacillus plantarum C19. International Journal of Food Microbiology, 68: 93-104.

Atterbury, R.J., Dillon, E., Swif,t, C., Connerton, P.L., Frost, J.A., Dodd, C.E., Rees, C.E. \& Connerton, I.F. 2005. Correlation of Campy- 
lobacter bacteriophage with reduced presence of hosts in broiler chicken ceca. Applied \& Environmental Microbiology, 71: 4885-4887.

Axelsson, L.T., Chung, T.C., Dobrogosz, W.J. \& Lindgren, S.E. 1989. Production of a broad spectrum antimicrobial substance by Lactobacillus reuteri. Microbial Ecology in Health and Disease, 2: 131-136.

Barbosa, M. S., Todorov, S. D., Ivanova I. V., Belguesmia, Y., Choiset, Y., Rabesona, H., Chobert. J.-M. Haertle, T., \& Franco, B.D.G.M. 2016. Characterization of a twopeptide plantaricin produced by Lactobacillus plantarum MBSa4 isolated from Brazilian salami. Food Control, 60: 103-112.

Bata, A., \& Lasztity, R. 1999. Detoxification of mycotoxin-contaminated food and feed by microorganisms. Trends in Food Science \& Technology, 10: 223-228.

Benech, R.-O., Kheadr, E.E., Lacroix, C. \& Fliss, I. 2002._Antibacterial activities of nisin $\mathrm{Z}$ encapsulated in liposomes or produced in situ by mixed culture during Cheddar cheese ripening. Applied \& Environmental Microbiology, 68: 5607-5619.

Bernbom, N., Licht, T. R., Saadbye, P., Vogensen, F. K., \& Nrrung. B. 2006. Lactobacillus plantarum inhibits growth of Listeria monocytogenes in an in vitro continuous flow gut model, but promotes invasion of L. monocytogenes in the gut of gnotobiotic rats. International Journal of Food Microbiology, 108: $10-14$.

Birkenhauer, J.M. \& Oliver, J.D. 2003. Use of diacetyl to reduce the load of Vibrio vulnificus in the Eastern oyster, Crassostrea virginica. Journal of Food Protection, 66:38-43.

Borneman, A.R., McCarthy, J.M., Chambers, P.J., $\&$ Bartowsky, E.J. 2012. Comparative analysis of the Oenococcus oeni pan genome reveals genetic diversity in industrially-relevant pathways. BMC Genom, 13:373 (2012). Doi: https://doi.org/10.1186/1471-2164-13-373.

Brul, S., \& Coote, P. 1999. Preservative agents in foods mode of action and microbial resistance mechanisms. International Journal of Food Microbiology, 50:1-17.
Brüssow, H., \& Kutter, E. 2005. Phage ecology. In: Bacteriophages: Biology and Applications. E. Kutter \& A. Sulakvelidze (Ed.), Florida: Boca Raton CRC Press. pp: 129-163.

Burgos, G.J., Pulido, R.P., Aguayo, L.G., Galvez, A. \& Lucas, R. 2014. The cyclic antibacterial peptide enterocin AS-48: Isolation, mode of action, and possible food applications. International Journal of Molecular Science,15: 22706-22727.

Chang, Y. 2020. Bacteriophage-derived endolysins applied as potent biocontrol agents to enhance food safety. Microorganisms, 8: 724. Doi:10.3390/microorganisms8050724.

Chen, Y.S., Wang, Y.C., Chow, Y.S., Yanagida, F., Liao, C.C. \& Chiu, C.M. 2014. Purification and characterization of plantaricin $\mathrm{Y}$, a novel bacteriocin produced by Lactobacillus plantarum 510. Archives of Microbiology, 196:193-199.

Cheong, E.Y.L., Sandhu, A., Jayabalan, J., Kieu Le, T. T., Nhiep, N. T., My Ho, H. T., \& Turner, M. S. 2014. Isolation of lactic acid bacteria with antifungal activity against the common cheese spoilage mould Penicillium commune and their potential as biopreservatives in cheese. Food Control, 46: 91-97.

Chrysan M.M. 2005. Margarines and spreads. In: Bailey's Industrial Oil and Fat Products. Bailey A. \& Shahidi F. (Eds.). Vol4. Hoboken, NJ: John Wiley \& Sons. pp: 32-82.

Chung, T.C., Axelsson, L., Lindgren, S.E. \& Dobrogosz, W.J. 1989. In vitro studies on reuterin synthesis by Lactobacillus reuteri. Microbial Ecology in Health and Disease, 2: 137-144.

Clark, S., Carl K., \& Winter, C.K. 2015. Diacetyl in foods: A review of safety and sensory characteristics. Comprehensive Reviews in Food Science and Food Safety, 14: 634-643.

Cotter, P.D., Hill, C. \&Ross, R.P. 2005. Bacteriocins: developing innate immunity for food. Nature Reviews Microbiology, 3: 777-788.

Crowley, S., Bottacini, F., Mahony, J., \& van Sinderen, D. 2013. Complete genome sequence of Lactobacillus plantarum strain 16, a broad-spectrum antifungal-producing lactic acid bacterium. Genome Announcements, 1: e00533-13. doi: 10.1128/genomeA.00533-13 
Dahiya, R.S., \& Speck, M.L. 1968. Hydrogen peroxide formation by lactobacilli and its effect on Staphylococcus aureus. Journal of Dairy Science, 51:1569-1572.

Datta, R., \& Henry, M. 2006. Lactic acid: recent advances in products, processes and technologies - a review. Journal of Chemical Technology \& Biotechnology, 81:1119-1129.

Devi, M.P., Bhowmick, N., Bhanusree, M.R. \& Ghosh, S.K. 2015. Preparation of value-added products through reservation. Springer India, 1: 113-124.

Diep, D.B., Myhre, R., Johnsborg, O., \& Aakra, A. 2003. Inducible bacteriocin production in Lactobacillus is regulated by differential expression of the pln operons and by two antagonizing response regulators, the activity of which is enhanced upon phosphorylation. Molecular Microbiology, 47: 483-494.

Dong, A.-R., Lo, R., Bansal, N., \& Turner, M.S. 2017. A genetic diversity study of antifungal Lactobacillus plantarum isolates. Food Control, 72: 83-89.

Drider, D., Fimland, G., Héchard, Y., McMullen, L.M., \& Prévost, H., 2006. The continuing story of class IIa bacteriocins. Microbiology \& Molecular Biology Reviews, 7: 564-582.

El-Ziney, M.G, De Meyer, H., \& Debevere, J. 1997. Growth and survival kinetics of Yersinia enterocolitica IP 383 0:9 as affected by equimolar concentrations of undissociated shortchain organic acids. International Journal Food Microbiology, 34:233-47.

El-Ziney, M.G., \& Debevere, J.M. 1998. The effect of reuterin on Listeria monocytogenes and Escherichia coli O157:H7 in milk and cottage cheese. Journal of. Food Protection, 61: 1275-1280.

El-Ziney, M., Debevere, J., \& Jakobsen, M. 2000. Reuterin In: Natural Food Antimicrobial Systems. Niadu A.S. (Ed). CRC press.

Enan, G., Essaway, A.A., Uyttendaele, M., \& Debeverea, J. 1996. Antibacterial activity of Lactobacillus plantarum UG1 isolated from dry sausages: Charcterization, production, and bactericidal action of plantaricin UG1. International Journal of Food Microbiology, 30: 189-215.

FAO, 1999. Manual on the use of the LP-system in milk handling and preservation. Rome: Food and Agriculture Organization of the United Nations.

Fricourt, B.V., Barefoot, S.F., Testin, R.F., \& Hayasaka, S.S. 1994. Detection and activity of plantaricin $\mathrm{F}$ an antibacterial substance from Lactobacillus plantarum BF001 isolated from processed channel catfish. Journal of Food Protection, 57: 698-702.

Gálvez, A., Abriouel, H., Lớpez, R. L., \& Ben, O.N. 2007. Bacteriocin-based strategies for food biopreservation. International Journal of Food Microbiology, 120: 51-70.

Gangoiti, M.V., Puertas, A.I., Hamet, M.F. Peruzzo, P.J., Llamas, M.G., Medrano, M., Prieto, A., Dueñas, M.T. \& Abraham A.G. 2017. Lactobacillus plantarum CIDCA8327: An $\alpha$-glucan producing-strain isolated from kefir grains. Carbohydrate Polymers, 170: 52-59.

Ganguly, S. 2013. Basic principles for effective food preservation: a review. International Journal of Pure Applied Bioscience, 1: 84-85.

Golneshin, A., Gor, M.-C., Williamson, N., Vezina, B., Van, T., May, B.K., \& Smith, A.T. 2020. Discovery and characterisation of circular bacteriocin plantacyclin B21AG from Lactiplantibacillus plantarum B21. Heliyon 6 (2020) e04715. Doi: https://doi. org/10.1016/j.heliyon.2020.e04715.

González, B., Arca, P., Mayo, B., \& Suárez, J.F. 1994. Detection, purification and partial characterization of plantaricin $\mathrm{C}$, a bacteriocin produced by a Lactobacillus plantarum strain of dairy origin. Applied and Environmental Microbiology, 60: 2158-2163.

Guidone, A., Zotta, T. \& Ross R.P. 2014. Functional properties of Lactobacillus plantarum strains: A multivariate screening study. LWT-Food Science and Technology, 56: 69-76.

Güler Z. \& Gürsoy-Balci A.C. 2011. Evaluation of volatile compounds and free fatty acids in set types yogurts made of ewes', goats' milk and their mixture using two different commercial starter cultures during refrigerated storage. Food Chemistry, 127: 1065-1071.

Gupta, R., \& Srivastava, S. 2014. Antifungal effect of antimicrobial peptides (AMPs LR14) derived from Lactobacillus plantarum strain LR/14 and their applications in prevention of grain spoilage. Food Microbiology, 42: 1-7. 
Hanlon, G.W. (2007). Bacteriophages: an appraisal of their role in the treatment of bacterial infections. International Journal of Antimicrobial Agents, 30: 118-128.

Holo, H., Jeknic, Z., Daeschel, M., Stevanovic, S., $\&$ Nes, I.F. 2001. Plantaricin W from Lactobacillus plantarum belongs to a new family of two-peptide lantibiotics. Microbiology, 147: 643-651.

Hu, M., Zhao, H., Zhang, C., Yu, J., \& Lu, Z. 2013. Purification and characterization of plantaricin 163, a novel bacteriocin produced by Lactobacillus plantarum 163 isolated from traditional Chinese fermented vegetables. Journal of Agricultural and Food Chemistry, 61: 11676-11682.

Hurst, A. 1981. Microbial antagonism in foods. Canadian Institute of Food Science \& Technology Journal, 6:80-89.

Jack, R.W., Tagg, J.R. \& Ray, B. 1995. Bacteriocins of Gram-positive bacteria. Archive of Microbiolpgical Reviews, 59:171-200.

Jay, M.J. 1982. Antimicrobial properties of diacety. Applied \& Environmental Microbiology, 44: 525-532.

Jiménez-Díaz, R., Rios-Sánchez, R.M.,Desmazeaud, M., Ruiz-Barba, J.L., \& Piard, J.C. 1993. Plantaricins $\mathrm{S}$ and $\mathrm{T}$, two new bacteriocins produced by Lactobacillus plantarum LPCO10 isolated from a green olive fermentation. Applied \& Environmental Microbiology, 59: 1416-1424.

Juodeikienea, G., Bartkieneb, E., Cernauskasa, Cizeikienea, D., Zadeikea, D., Leleb, V., \& Bartkevics, V. 2018. Antifungal activity of lactic acid bacteria and their application for Fusarium mycotoxin reduction in malting wheat grains. LWT - Food Science and Technology, 89: 307-314.

Kanatani, K., \& Oshimura, M. 1994. Plasmid-associated bacteriocin production by a Lactobacillus plantarum strain. Bioscience, Biotechnology and Biochemistry, 58: 2084-2086.

Kato, T., Matsuda, T., Ogawa, E., Kato, H., Doi, U., \& Nakamura, R. 1994. Plantaricin-149, a bacteriocin produced by Lactobacillus plantarum NRIC 149. Journal of Fermentation and Bioengineering, 77: 277-282.

Kim, J.-D. 2005. Antifungal activity of lactic acid bacteria isolated from kimchi against Aspergillus fumigatus. Mycobiology, 33: 210-214.
Kim, K.P., Klumpp, J. \& Loessner, M.J. 2007. Enterobacter sakazakii bacteriophages can prevent bacterial growth in reconstituted infant formula. International Journal Food Microbiology, 115: 195-203.

Kim, Y., Ryu, Y., Kim, B.H., Yoo, J., An, W., Kim, D.R., Kwon, B.-Y., Lee, S., Wang, Y., Kim, K. \& Kim, D. 2017. Characterization of a novel SGNH-type esterase from Lactobacillus plantarum. International Journal of Biological Macromolecules, 96: 560-568.

Klaenhammer, T. R. 1993. Genetics of bacteriocins produced by lactic acid bacteria. EMS Microbial Review, 12: 39-87.

Krishnan, S., Gowda, L.R. \& Karanth, N.G. 2000. Studies on lactate dehydrogenase of Lactobacillus plantarum spp. Involved in lactic acid biosynthesis using permeabilized cells. Process Biochemistry, 35: 1191-1198.

Kussendrager, K.D., \& van Hooijdonk, A.C.M. 2000. Lactoperoxidase: Physico-chemical properties, occurrence, mechanism of action and applications. British Journal of Nutrition, 84: S19-S25.

Kwak, M.K., Liu, R., \& Kang, S.O. 2017. Antimicrobial activity of cyclic dipeptides produced by Lactobacillus plantarum LBPK10 against multidrug-resistant bacteria, pathogenic fungi, and influenza A virus. Food Control, 85: 223-234.

Lavermicocca, P., Valerio, F., Evidente, A., Lazzaroni, S., Corsetti, A., \& Gobetti, M. 2000. Purification and characterization of novel antifungal compounds from the sourdough $\mathrm{Lac}$ tobacillus plantarum strain $\quad r$ B. Applied \& Environmental Microbiology, 66:40844090.

Lee, K. W., Shim, J. M., Park S.-K. Heo, H.-J., Kim, H.-J., Ham, H.-J., Ham, K.S., \& Kim, J.H. 2016. Isolation of lactic acid bacteria with probiotic potentials from kimchi, traditional Korean fermented vegetable. LWT- Food Science and Technology, 71: 130-137.

López-Cuellar, M.R., Rodríguez-Hernández, A.-I. \& Chavarría-Hernández, N. 2016. LAB bacteriocin applications in the last decade. Biotechnology and Biotechnol. Equipment, 30: 1039-1050.

Li, P., Gu, Q., Yang, L., Yu, Y., \& Wang, Y. 2017. Characterization of extracellular vitamin B12 producing Lactobacillus plantarum strains 
and assessment of the probiotic potentials. Food Chemistry, 234: 494-501.

Lin T.-H., \& Pan T.-M. 2017. Characterization of an antimicrobial substance produced by Lactobacillus plantarum NTU 102. Journal of Microbiology, Immunology \& Infection, 52: 1-9.

Lindgren, E., \& Dobrogosz, J. 1990. Antagonistic activities of lactic acid bacteria in food and feed fermentations. FEMS Microbiology Review, 87: 149-164.

Lins, L., Ducarme, P., Breukink, E., \& Brasseur, R. 1999. Computational study of nisin interaction with model membrane. Biochimica Biophysica Acta, 1420: 111-120.

Liu, S.-N., Han,Y., \& Zhou, Z.-J. 2011. Lactic acid bacteria in traditional fermented Chinese foods. Food Research International, 44: 643651.

Luck, H. 1962. The use of hydrogen peroxide in milk and dairy products. In: Milk Hygiene: Hygiene in Milk Production, processing and Distribution (pp. 423-447). Geneva: World Health Organization.

Luz, C., Saladino, F., Luciano, F. B., Mặnes, J., \& Meca, G. 2017. In vitro antifungal activity of bioactive peptides produced by Lactobacillus plantarum against Aspergillus parasiticus and Penicillium expansum. LWT - Food Science and Technology, 81: 128-135.

Lv, X., Ma, R., H.H., Lin, Y., Bai, F.L., Ge, Y.H., Zhang, D.F., \& Li, J.R. 2018a. Antifungal activity of Lactobacillus plantarum C10 against Trichothecium roseum and its application in promotion of defense responses in muskmelon (Cucumis melo L.) fruit. Journal of Food Science and Technology-Mysore, 55: 3703-3711.

Lv, X., Lin, Y., Jie, Y., Sun, M., Zhang, B., Bai, F., Zhao, H., \& Li, J. 2018b. Purifcation, characterization, and action mechanism of plantaricin DL3, a novel bacteriocin against Pseudomonas aeruginosa produced by Lactobacillus plantarum DL3 from Chinese SuanTsai. European Food Research and Technology, 244:323-331.

Magnusson, J., Ström, K., Roos, S., Sjögren, J., \& Schnürer, J. 2003. Broad and complex antifungal activity among environmental isolates of lactic acid bacteria. FEMS Microbiology
Letters, 219:129-135.

Magnusson, J. \& Schnurer, J. 2001. Lactobacillus coryniformis subsp. coryniformis strain $\mathrm{Si} 3$ produces a broad-spectrum proteinaceous antifungal compound. Applied and Environmental Microbiology, 67: 1-5.

Makhal, S., Kanawjia, K., \& Aupurbe, G. 2015. Effect of microGARD ${ }^{\circledR}$ on keeping quality of direct acidified Cottage cheese. Journal of Food Science and Technology, 52: 936-943.

Malti, J.E., \& Amarouch H. 2008. Protective cultures used for the biopreservation of horse meat fermented sausage: Microbial and physicochemical characterization. Journal of Food Safety 28:324-345.

Messaoudi, S., M. Manai, G. Kergourlay, H. Prévost, N. Connil, J.M. Chobert, \& X. Dousset 2013. Lactobacillus salivarius: Bacteriocin and probiotic activity. Food Microbiology, 36: 296-304.

Messi, P., Bondi, M., Sabia, C., Battini, R., \& Manicardi, G. (2001). Detection and preliminary characterization of a bacteriocin (plantaricin 35d) produced by a Lactobacillus plantarum strain. International Journal of Food Microbiology, 64: 193-198.

Milicevic, D., Nastasijevic, I., \& Petrovic, Z. 2016. Mycotoxin in the food supply chain implications for public health program. Journal of Environmental Science and Health Part C: Environmental Carcinogenesis \& Ecotoxicology Reviews, 34: 293-319.

Moye, Z.D., Woolstone, J., \& Sulakvelidze, A. 2018. Bacteriophage Applications for Food Production and Processing. Viruses, 10: $1-22$.

Muhialdin, B. J., Hassan, Z., Abu Bakar, F., \& Saari, N. 2016. Identification of antifungal peptides produced by Lactobacillus plantarum IS10 grown in the MRS broth. Food Control, 59: 27-30.

Murofushi, Y., Villena, J., Morie, K., Kanmani, P., Tohno, M., Shimazu, T., Aso, H., Suda, Y., Hashiguchi, K., Saito, T. \& Kitazawa, H. 2015. The toll-like receptor family protein RP105/ MD1 complex is involved in the immunoregulatory effect of exopolysaccharides from Lactobacillus plantarum N14. Molecular Immunology, 64: 63-75. 
Nakanishi, K., Tokuda, H., Ando, T., Yajima, M., Nakajima, T., Tanaka, O. \& Ohmomo, S. 2002. Screening of lactic acid bacteria having the ability to produce reuterin. Japanese Journal of Lactic Acid Bacteria, 13: 37-45.

Nath, S. Chowdhury, S., Dora, K.C., \& Sarkar, S. 2014. Role of bio-preservation in improving food safety and storage. Journal of Engineering Research \& Applications, 4: 26-32.

Oliveira, H., Melo, L.D., Santos, S.B., Nóbrega, F.L., Ferreira, E.C., Cerca, N., Azeredo, J., \& Kluskens, L.D. 2013. Molecular aspects and comparative genomics of bacteriophage endolysins. Journal Virology, 87 : 4558-4570.

Ortiz-Rivera, Y., Sánchez-Vega, R., GutiérrezMéndez, N., León-Félix, J., Acosta-Muñiz, C., \& Sepulveda, D.R. 2016. Production of reuterin in a fermented milk product by Lactobacillus reuteri: Inhibition of pathogens, spoilage microorganisms, and lactic acid bacteria. Journal Dairy Science, 100: 42584268.

Panda, S.H. \& Ray, R.C. 2008. Direct conversion of raw starch to lactic acid by Lactobacillus plantarum MTCC 1407 in semi-solid fermentation using sweet potato (Ipomoea batatas L.) flour. Journal of Scientific and Industrial Research, 67: 531-537.

Panda, S.K., Ray, R.C., Mishra, S.S. \& Kayitesi, E. 2017. Microbial processing of fruit and vegetable wastes into potential biocommodities: a review. Critical Reviews in Biotechnology, 38: $1-16$.

Papagianni, M. \& Anastasiadou, S. 2009. Pediocins: The bacteriocins of Pediococci. Sources, production, properties and applications. Microbial Cell Factories, 8: 3 (2009). Doi: https://doi.org/10.1186/1475-2859-8-3

Pawlowska, A.M., Zannini, E., Coffey, A., \& Arendt, E.K. 2012. Green preservatives: Combating fungi in the food and feed industry by applying antifungal lactic acid bacteria. Advances in Food and Nutrition Research, 66: 217-238.

Pelaez, A.M., Catano, C.A., Yepes, E.A., Villarroela, R.R., De Antoni, G.L., \& Giannuzzi, L. 2012. Inhibitory activity of lactic and acetic acid on Aspergillus flavus growth for food preservation. Food Control, 24:177-183.

Pitt, J.I., \& Hocking, A.D. 2009. Fungi and Food Spoilage. Boston, MA: Springer, pp. 1-9.
Quattrini, M., Bernardi, C., Stuknyte, M., Masotti, F., Passera, A., Ricci, G. \& Fortina, M.G. 2018. Functional characterization of Lactobacillus plantarum ITEM 17215: A potential biocontrol agent of fungi with plant growth promoting traits, able to enhance the nutritional value of cereal products. Food Research International, 106: 936-944.

Rather, I.A., Seo, B.J., Kumar, V.J., Choi, U.H., Choi, K.H., Lim, J.H., \& Park, Y.H. 2013. Isolation and characterization of a proteinaceous antifungal compound from Lactobacillus plantarum YML007 and its application as a food preservative. Letters in Applied Microbiology, 57: 69-76.

Ray, B. 2004. Fundamental Food Microbiology. CRC Press, Boca Raton, pp. 227-229.

Raya, R.R., Varey, P., Oot, R.A., Dyen, M.R., Callaway, T.R., Edrington, T.S., Kutter, E.M. \& Brabban, A.D. 2006. Isolation and characterization of a new T-even bacteriophage, CEV1, and determination of its potential to reduce Escherichia coli O157:H7 levels in sheep. Applied \& Environmental Microbiology, 72: 6405-6410.

Rekhif, N., Atrih, A., \& Lefebvre, G. 1995. Activity of plantaricin SA6, a bacteriocin produced by Lactobacillus plantarum SA6 isolated from fermented sausage. Journal of Applied Bacteriology, 78: 349-358.

Rekhif, N., Atrih, A., \& Lefebvre, G. 1994. Characterization and partial purification of plantaricin LC74, a bacteriocin produced by Lactobacillus plantarum LC74. Biotechnology Letters, 16: 771-776.

Reis, J.A., Paula, A.T., Casarotti, S.N. \& Penna, A.L. 2012. Lactic acid bacteria antimicrobial compounds: characteristics and applications. Food Engineering Reviews, 4:124-140.

Ross, P.R., Morgan, S., \& Hill, C. 2002. Preservation and fermentation: past, present and future. International Journal of Food Microbiology, 79: 3-16.

Russo, P., Arena, M.P., Fiocco, D., Capozzi, V., Drider, D., \& Spano, G. 2017. Lactobacillus plantarum with broad antifungal activity: A promising approach to increase safety and shelf-life of cereal-based products. International Journal of Food Microbiology, 247: 48-54. 
Sahl, H.G., \& Bierbaum, G. 1998. Lantibiotics: biosynthesis and biological activities of uniquely modified peptides from Gram-positive bacteria. Annual Review of Microbiology, 52: 41-79.

Saladino, F., Luz, C., Manyes, L., Fernandez-Franzon, M., and Meca, G. 2016. In vitro antifungal activity of lactic acid bacteria against mycotoxigenic fungi and their application in loaf bread shelf life improvement. Food Control, 67: 273-277.

Salas, L.M., Mounier, J., Valence, F., Coton, M., Thierry, A., \& Coton, E. 2017. Antifungal microbial agents for food biopreservation-a review. Microorganisms 5: E37.

Salas, L.M., Thierry, A., Lemaître, M., Garric, G., Marielle, M., Chatel, M., Lê Mounier, S.J., Valence, F. \& Coton, E. 2018. Antifungal aca tivity of lactic acid bacteria combinations in dairy mimicking models and their potential as bioprotective cultures in pilot scale applications. Frontiers in Microbiology, 9: doi: 10.3389/fmicb.2018.01787.

Schillinger, U., Geisen, R., \& Holzapfel, W.H. 1996. Potential of antagonistic microorganisms and bacteriocins for the biological preservation of foods. Trends in Food Science and Technology, 7: 158-164.

Seifua, E., Buys, E.M., \& Donkin, E.F. 2005. Significance of the lactoperoxidase system in the dairy industry and its potential applications: a review. Trends in Food Science and Technology 16: $137-154$.

Severina, E., Severin, A. and Tomasz. A. 1998. Antibacterial efficacy of nisin against multidrugresistant Gram-positive pathogens. Journal of Antimicrobial Chemotherapy, 41:341-347.

Sharma, R., Sanodiya, B.S., Bagrodia, D., Pandey, M., Sharma, A., \& Bisen, P.S. 2012. Efficacy and Potential of Lactic Acid Bacteria Modulating Human Health. International Journal of Pharma and Bio Sciences, 3: 935-948.

Singh, V.P. 2018. Recent approaches in food biopreservation - a review. Open Veterinary Journal, 8: 104-111.

Song, D.F., Zhu, M.Y., \& Gu, Q. 2014. Purification and characterization of plantaricin ZJ5, a new bacteriocin produced by Lactobacillus plantarum ZJ5. PLoS One, 9: 1-8.
Steele, J., Broadbent, J., \& Kok, J. 2013. Perspective on the contribution of lactic acid bacteria to cheese flavor development. Current Opinion in Biotechnology, 24: 135-141.

Suomalainen, T.H., Mayra, M., \& Makinen, A.M. 1999. Propionic acid bacteria as protective cultures in fermented milks and breads. Lait, 79:165-174.

Swain, M.R. \& Ray, R.C. 2016. Nutritional values and bioactive compounds in fermented fruits and vegetables, in Lactic Acid Fermentation of Fruits and Vegetables, Paramethioites, S. Ed., pp. 37-52, CRC Press, Boca Raton, Fla, USA.

Tchorbanov, B., Marinova, M., \& Grozeva, L. 2011. Debittering of protein hydrolysates by Lactobacillus LBL-4 aminopeptidase. Enzyme Research, article ID 538676, doi: $10.4061 / 2011 / 538676$

Thomas, L.V., Clarkson, M.R., \& DelvesBroughton, J. 2000. Nisin. In: Naidu, A.S. (Ed.), Natural food antimicrobial systems. CRC Press, Boca-Raton, FL, pp. 463-524.

Todorov, S.D., Holzafel, W., \& Nero, L.A. 2016. Characterization of a novel bacteriocin produced by Lactobacillus plantarum ST8SH and some aspects of its mode of action. Annals of Microbiology, 66: 949-962.

Todorov, S.D. \& Dicks, L.M. 2005. Lactobacillus plantarum isolated from molasses produces bacteriocins active against Gram-negative bacteria. Enzyme and Microbial Technology, 36: 318-326.

Turner, M.S., Waldherr, F., Loessner, M.J. \& Giffard, P.M. 2007. Antimicrobial activity of lysostaphin and a Listeria monocytogenes bacteriophage endolysin produced and secreted by lactic acid bacteria. Systematic Applied Microbiology, 30: 58-67.

Uppada, S.R., Akula, M., Bhattacharya, A. \& Dutta, J. R. 2017. Immobilized lipase from Lactobacillus plantarum in meat degradation and synthesis of flavor esters. Journal of Genetic Engineering and Biotechnology, 15: 331334.

Van Reenen, C.A., Dicks, L.M., \& Chikindas, M.L. 1998. Isolation, purification and partial characterization of plantaricin 423, a bacteriocin produced by Lactobacillus plantarum. Journal of Applied Microbiology, 84: 1131-1137. 
Varsha, K.K., \& Nampoothiri, K.M. 2016. Appraisal of lactic acid bacteria as protective cultures. Food Control, 69: 61-64.

Wang, J., Zhao, X., Tian, Z., Yang, Y. \& Yang, Z. 2015. Characterization of an exopolysaccharide produced by Lactobacillus plantarum YW11 isolated from Tibet Kefir. Carbohydrate Polymers, 125: 16-25.

Wang, Y., Li, C., Liu, P., Ahmed, Z., Xiao, P. \& Bai, X. 2010. Physical characterization of exopolysaccharide produced by Lactobacillus plantarum KF5 isolated from Tibet Kefir. Carbohydrate Polymers, 82: 895-903.

Wee, Y.J., Kim, J.N., \& Ryu, H.W. 2006. Biotechnological production of lactic acid and its recent applications. Food Technology \& Biotechnology, 44: 163-172.

Wen, L. S., Philip, K., \& Ajam, N. 2016. Purification, characterization and mode of action of plantaricin K25 produced by Lactobacillus plantarum. Food Control, 60: 430-439.

Wiedemann, I., Breukink, E., van Kraaij, C., Kuipers, O.P., Bierbaum, G., de Kruijff, B., \& Sahl, H.G. 2001. Specific binding of nisin to the peptidoglycan precursor lipid II combines pore formation and inhibition of cell wall biosynthesis for potent antibiotic activity. Journal of Biological Chemistry, 276: 1772-1779.

Wolfson, L.M., \& Sumner, S.S. 1993. Antibacterial activity of the lactoperoxidase system: A review. Journal of Food Protection, 56: 887-892.

Xie, L., \& van der Donk, W.A. 2004. Post-translational modifications during lantibiotic biosynthesis. Current Opinion in Chemical Biology, 8: 498-507.

Xinran, L., Luhuan, M., Huanhuan, M., Fengling, B., Yang, L., Mengtong, S. \& Jianrong. L.
2018. Purification, characterization and action mechanism of plantaricin JY22, a novel bacteriocin against Bacillus cereus produced by Lactobacillus plantarum JY22 from golden carp intestine. Food Science and Biotechnology, 27: 695-703.

Yoong, P., Schuch, R., Nelson, D. \& Fischetti, V.A. 2004. Identification of a broadly active phage lytic enzyme with lethal activity against antibiotic resistant Enterococcus faecalis and Enterococcus faecium. Journal of Bacteriology, 186: 4808-4812.

Young, R.Y., Wang, I.N. \& Roof, W.D. 2005. Phages will out: strategies of host cell lysis. Trends in Microbiology, 8: 120-128.

Zhang, L., Liu, C., Li, D., Zhao, Y., Zhang, X., Zeng, X., Yang, Z. \& Li, S. 2013. Antioxidant activity of an exopolysaccharide isolated from Lactobacillus plantarum C88. International Journal of Biological Macromolecules, 54: 270-275.

Zhao, S., Han, J., Bie, X., Lu, Z., Zhang, C., \& Lv, F. 2016. Purification and characterization of plantaricin JLA-9: a novel bacteriocin against Bacillus spp. produced by Lactobacillus plantarum JLA-9 from Suan-Tsai, a traditional Chinese fermented cabbage. Journal of Agricultural Food Chemistry, 64:2754-2764.

Zhou, K., Zeng, Y., Yang, M., Chen, S., He, L., Ao, X., Zou, L. \& Liu, S. 2016. Production, purification and structural study of an exopolysaccharide from Lactobacillus plantarum BC25. Carbohydrate Polymers, 144: 205-214.

Zhu, X., Zhao, Y., Sun, Y., \& Gu, Q. 2014. Purification and characterization of plantaricin ZJ008, a novel bacteriocin against Staphylococcus spp. from Lactobacillus plantarum ZJ008. Food Chemistry, 165: 216-223. 


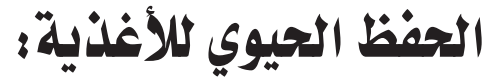 \\ Lactobacillus plantarum نظرة شاملة على الاهتمام بالنوع}

نهى خليل، نصرة دبور، محمد الزينى، إيهاب خضر

قسم علوم و تقنية الألبان - كلية الزراعة - جامعة الأسكندرية - الشاطبى - الرقم البريدى

$$
\text { مصر }
$$

لقد حظى الحفظ الحيوي للأغذية باهتمام كبير خلال العقد الماضي. و يعتبر الحفظ الحيوي بديلاً واعدًا

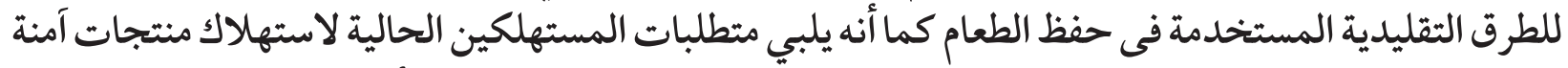

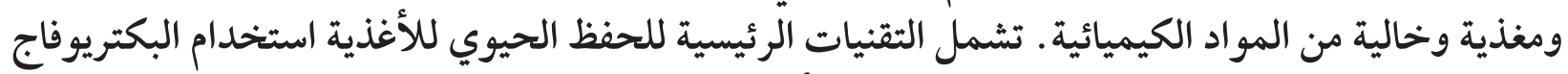

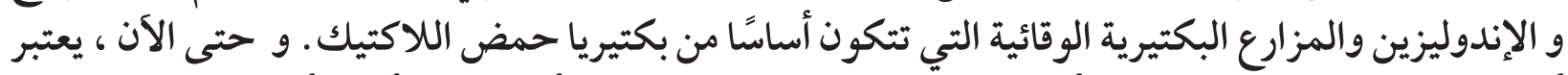

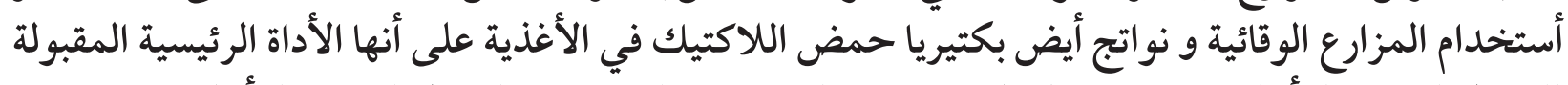

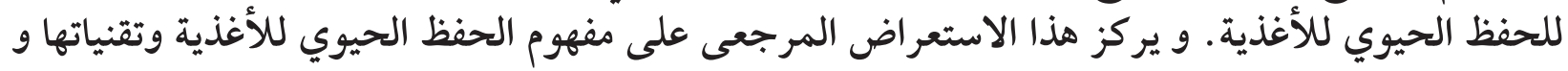

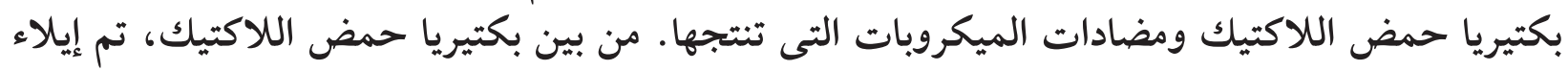

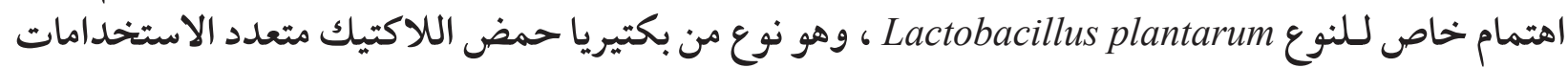
و له نشاط مهم فى تثبيط نمو الميكروبات المرضية وتلك المسببة لفساد الأغذية. 